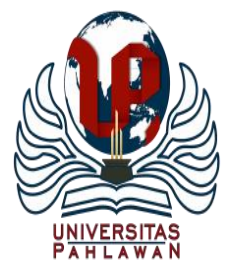

Edukatif : Jurnal Ilmu Pendidikan Volume 3 Nomor 2 Tahun 2021 Halm 496 - 504 EDUKATIF: JURNAL ILMU PENDIDIKAN

Research \& Learning in Education

https:/ledukatif.org/index.php/edukatif/index

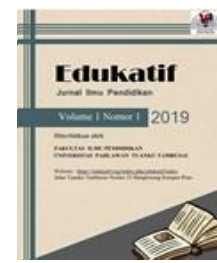

\title{
Perbedaan Model Problem Based Learning dan Project Based Learning Terhadap Hasil Belajar Siswa Sekolah Dasar
}

\author{
Francisca Prabasari Winanti Putri ${ }^{1 凶}$, Henny Dewi Koeswanti ${ }^{2}$, Sri Giarti $^{3}$ \\ Universitas Kristen Satya Wacana Salatiga ${ }^{1,2,3}$

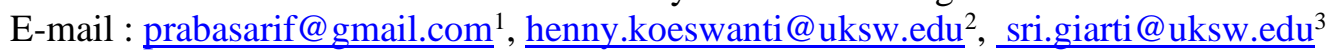

\begin{abstract}
Abstrak
Problem based learning dan project based learning merupakan model pembelajaran yang mampu membangkitkan potensi peserta didik dalam menggunakan kemampuan berpikir, sehingga dapat memecahkan permasalahan yang dihadapi. Penelitian ini bertujuan untuk mengetahui perbedaan antara model problem based learning dan project based learning ditinjau dari hasil belajar tema 7 siswa kelas IV SDN Kecamatan Tingkir. Teknik pengambilan sampel menggunakan jenis probability sampling design dengan teknik mengundi. Sampel pada penelitian adalah siswa kelas IV SDN Gendongan-01 (23 siswa), SDN Gendongan-03 (23 siswa), SDN Sidorejo Kidul-03 (21 siswa) sebagai kelompok eksperimen dan SDN Kutowinangun-01 (24 siswa), SDN Kutowinangun-10 (20 siswa), SDN Kutowinangun-11 (22 siswa) sebagai kelompok kontrol. Instrumen pengumpulan data berupa instrumen tes. Sebelum dilaksanakan penelitian, dilaksanakan uji prasyarat terlebih dahulu. Hasil dari uji prasyarat menunjukkan kedua kelompok tersebut homogen dan berdistribusi tidak normal. Penelitian dianalisis menggunakan uji beda mann-withney dan diperoleh nilai Asymp. Sig. (2tailed) sebesar $0,009<\alpha 0,05$. Berdasarkan hasil penelitian, maka dapat disimpulkan bahwa terdapat perbedaan hasil belajar antara penerapan model problem based learning dengan project based learning terhadap hasil belajar tema 7 siswa kelas IV SDN Kecamatan Tingkir. Penerapan model project based learning memberikan pengaruh yang lebih tinggi daripada model problem based learning terhadap hasil belajar peserta didik. Hal tersebut didukung oleh rata-rata nilai posttest pada model problem based learning sebesar 82,6263 dan model project based learning sebesar 94,2288.
\end{abstract}

Kata Kunci: Problem Based Learning, Project Based Learning, hasil belajar.

\begin{abstract}
Problem based learning and project based learning are learning model that are able to generate students' potential in using thinking skills and problem solving skills. This study aims to find out the difference between problem based learning and project based learning reviewed from grade IV students' learning outcomes after learning theme 7 at SDN Kecamatan Tingkir. Sampling techniques used was probability sampling design with lottery techniques. The sample in the study were grade IV students at SDN Gendongan-01 (23 students), SDN Gendongan-03 (23 students), SDN Sidorejo Kidul-03 (21 students) as experimental group and SDN Kutowinangun-01 (24 students), SDN Kutowinangun-10 (20 students), SDN Kutowinangun-11 (22 students) as control group. Data collection instruments in the form of test instruments. Before the research was carried out, a prerequisite test was carried out first. The results of prerequisite test showed both groups were homogeneous and abnormally distributed. The research was analyzed using different mannwithney tests and obtained Asymp values. Sig. (2-tailed) of $0.009<\alpha 0.05$, meaning there is a difference in students' learning outcomes in learning theme 7 using problem based learning and project based learning. The implementation of project based learning model has a higher effect than the problem based learning model on students' learning outcomes. It was supported by the average of students' grade in the posttest using problem based learning model of 82.6263 and the project based learning model of 94.2288 .
\end{abstract}

Keywords: Problem Based Learning, Project Based Learning, learning outcomes.

Copyright (c) 2021 Francisca Prabasari Winanti Putri, Henny Dewi Koeswanti, Sri Giarti $\triangle$ Corresponding author

Email : prabasarif@gmail.com

DOI : https://doi.org/10.31004/edukatif.v3i2.356

ISSN 2656-8063 (Media Cetak)

ISSN 2656-8071 (Media Online)

Edukatif : Jurnal Ilmu Pendidikan Vol 3 No 2 Tahun 2021 p-ISSN 2656-8063 e-ISSN 2656-8071 


\section{PENDAHULUAN}

Pendidikan merupakan suatu usaha yang dilaksanakan secara sadar dan terencana untuk menciptakan kegiatan pembelajaran yang aktif dan kontekstual, sehingga peserta didik mampu mengembangkan keterampilan, pengetahuan, dan sikap yang terdapat di dalam dirinya. Inti dari proses pendidikan adalah kurikulum. Sukmadinata (2012) berpendapat bahwa kurikulum merupakan bidang yang paling berpengaruh terhadap hasil pendidikan. Undang-undang Nomor 20 Tahun 2003 tentang Sistem Pendidikan Nasional (Depdiknas, 2003) menyatakan bahwa kurikulum merupakan seperangkat rencana dan pengaturan mengenai bahan pembelajaran, isi, tujuan, serta cara yang digunakan sebagai pedoman penyelenggaraan kegiatan untuk mencapai tujuan pendidikan. Kurikulum mencakup dua dimensi, yaitu rencana dan pengaturan mengenai bahan pembelajaran, isi, serta tujuan, cara yang digunakan dalam melaksanakan kegiatan pembelajaran.

Seiring berjalannya waktu, kurikulum di Indonesia telah mengalami banyak perkembangan. Kurikulum 2013 merupakan kurikulum baru yang dirancang berdasarkan paradigma pendidikan abad 21. Inti dari kurikulum tersebut mewajibkan peserta didik untuk mampu mengikuti tantangan kemajuan ilmu pengetahuan di abad 21. Pengembangan kurikulum tersebut turut mengubah muatan maupun model pembelajaran yang digunakan. Proses pembelajaran yang kreatif dan mengedepankan pengalaman pribadi (mengamati, menanya, menalar, dan mencoba) sangat dibutuhkan untuk mendukung kegiatan pembelajaran berbasis kurikulum 2013.

Pembelajaran yang digunakan pada kurikulum 2013 merupakan pengembangan dari pembelajaran tematik integratif yang mengacu pada kurikulum 2006. Pembelajaran tematik integratif merupakan salah satu upaya pembelajaran terpadu yang bertujuan untuk melibatkan peserta didik dalam kegiatan pembelajaran, baik secara individu maupun kelompok, sehingga peserta didik dapat lebih aktif dalam menggali kemampuannya sendiri. Lampiran Peraturan Menteri Pendidikan dan Kebudayaan Republik Indonesia Nomor 67 Tahun 2013 tentang Kerangka Dasar dan Struktur Kurikulum SD/MI (Kemendikbud, 2013a) menyatakan bahwa pembelajaran tematik merupakan pembelajaran yang dapat dilaksanakan pada seluruh kelas, yaitu kelas rendah (1-3) dan kelas tinggi (4-6). Sani (2014) berpendapat bahwa kegiatan pembelajaran yang dilaksanakan wajib melibatkan aspek keterampilan, pengetahuan, dan sikap, sehingga mampu menghasilkan pemikiran yang lebih efektif. Selain itu, peserta didik diharapkan mampu berpikir dengan menemukan konsep secara mandiri.

Peraturan Menteri Pendidikan dan Kebudayaan Nomor 81A Tahun 2013 Lampiran IV (Kemendikbud, 2013b) menyebutkan bahwa kurikulum 2013 menganut pandangan bahwa pengetahuan tidak dapat dipindahkan begitu saja dari pengajar ke peserta didik. Berdasarkan hal tersebut, maka kurikulum 2013 mulai menerapkan pendekatan pembelajaran scientific. Pendekatan pembelajaran scientific merupakan pendekatan pembelajaran yang dirancang dengan sedemikian rupa supaya peserta didik dapat secara aktif membangun hukum, konsep, atau prinsip melalui tahap mengidentifikasi permasalahan, merumuskan permasalahan, mengajukan atau merumuskan hipotesis, mengumpulkan data dengan berbagai teknik, menganalisis data, serta membuat kesimpulan dan mengkomunikasikan hukum, konsep, atau prinsip yang telah ditemukan (Sufairoh, 2016).

Model pembelajaran yang sesuai dengan kurikulum 2013 diwajibkan untuk dapat menciptakan keaktifan peserta didik pada saat kegiatan pembelajaran berlangsung. Kegiatan pembelajaran yang baik wajib lebih efisien, mempunyai sistem pendekatan yang sesuai, perlu adanya minat dan perhatian peserta didik dalam belajar, serta terprogram dan tertata (Suyono Hariyanto, 2011). Sejalan dengan hal tersebut, Taniredja (2011) juga berpendapat bahwa kegiatan pembelajaran wajib dirancang untuk menambah pengetahuan peserta didik dengan memperhatikan isi atau pesan yang hendak disampaikan kepada peserta didik, karakteristik peserta didik, dan kesesuaian dengan materi pembelajaran. Sani (2014) berpendapat bahwa model pembelajaran yang sesuai dengan kurikulum 2013, antara lain inquiry based learning, discovery learning, 
problem based learning, project based learning, dan problem solving. Model-model pembelajaran tersebut dianggap sesuai dengan kurikulum 2013.

Model problem based learning merupakan suatu model pembelajaran yang diawali dengan memberikan suatu permasalahan pada peserta didik. Permasalahan yang diberikan wajib berkaitan dengan permasalahan yang sering dijumpai oleh peserta didik di dalam kehidupan sehari-hari dan bersifat autentik. Peserta didik dilatih untuk memecahkan permasalahan secara mandiri. Melalui kegiatan memecahkan permasalahan, peserta didik diharapkan mampu berproses dalam mencari penyelesaian atas permasalahan tersebut (Koeswanti, 2015). Menyelesaikan permasalahan dapat membantu peserta didik untuk berpikir pada tingkat yang lebih tinggi, sehingga berpengaruh terhadap hasil belajar peserta didik.

Model pembelajaran selanjutnya adalah model project based learning. Hosnan (2014) berpendapat bahwa model project based learning merupakan suatu model pembelajaran yang memberi kesempatan bagi peserta didik untuk mengelola kegiatan pembelajaran di kelas dengan melibatkan kegiatan proyek sebagai media pembelajaran. Kelebihan dari model tersebut adalah peserta didik mampu menghasilkan sebuah proyek dalam kegiatan pembelajaran secara mandiri. Peserta didik dibuat seolah-olah bekerja di dunia nyata dan menghasilkan sesuatu yang dapat bermanfaat. Hal tersebut memberikan penekanan pada keterampilan dan kemampuan berpikir kritis peserta didik.

Pada hakikatnya, model problem based learning dan project based learning memberikan penekanan pada pemecahan suatu permasalahan. Kedua model pembelajaran tersebut bertujuan untuk menciptakan kegiatan pembelajaran yang aktif dan berbobot, sehingga antusiasme peserta didik dapat meningkat. Apabila minat belajar peserta didik mengalami peningkatan, maka hasil belajar peserta didik tentu juga meningkat. Selain hal tersebut, peserta didik juga diajak untuk membangun pengetahuan baru yang dianalisis ke dalam dunia nyata.

Fiana et al. (2019) melaksanakan penelitian tentang perbedaan penerapan model problem based learning dan project based learning terhadap hasil belajar matematika kelas 4 sekolah dasar. Dalam penelitiannya, analisis hasil penelitian menggunakan uji beda mann-withney menunjukkan bahwa terdapat perbedaan hasil belajar matematika yang signifikan antara peserta didik yang diberi perlakuan model problem based learnig dengan peserta didik yang diberi perlakuan model project based learning. Hal tersebut dibuktikan dengan nilai Asymp. Sig. (2-tailed) sebesar 0,010< $\alpha 0,05$.

Berdasarkan permasalahan tersebut, peneliti merasa ragu tentang efektivitas model problem based learning dan project based learning, maka peneliti hendak melaksanakan penelitian dengan judul "Perbedaan Model Problem Based Learning dan Project Based Learning Terhadap Hasil Belajar Tema 7 Siswa Kelas IV SDN Kecamatan Tingkir". Penelitian tersebut dilaksanakan untuk mengetahui perbedaan antara hasil belajar peserta didik yang diberi perlakuan dengan menggunakan model problem based learning dengan peserta didik yang diberi perlakuan dengan menggunakan model project based learning. Hasil penelitian ini dapat dijadikan sebagai acuan bagi pengajar dalam memilih model pembelajaran yang sesuai untuk diterapkan dalam kegiatan pembelajaran.

\section{METODE PENELITIAN}

Jenis penelitian eksperimen yang digunakan adalah penelitian eksperimen semu (quasi experimental research) dengan rancangan penelitian non-equivalent control group design. Penelitian ini dilaksanakan pada 6 Sekolah dasar negeri yang terletak di Kecamatan Tingkir, Salatiga, Jawa Tengah. SDN Gendongan-01 berjumlah 23 peserta didik, SDN Gendongan-03 berjumlah 23 peserta didik, dan SDN Sidorejo Kidul-03 berjumlah 21 peserta didik dipilih sebagai kelompok eksperimen, sedangkan SDN Kutowinangun-01 
berjumlah 24 peserta didik, SDN Gendongan-10 berjumlah 22 peserta didik, dan SDN Gendongan-11 berjumlah 20 peserta didik dipilih sebagai kelompok kontrol. Muatan pembelajaran yang diteliti adalah ilmu pengetahuan alam dengan mengambil topik "gaya" yang didasarkan pada kompetensi dasar 3.3 Mengidentifikasi macam-macam gaya, antara lain: gaya otot, gaya listrik, gaya magnet, gaya gravitasi, dan gaya gesekan.

Langkah yang dilakukan dalam penelitian ini adalah mengambil nilai kompetensi dasar 3.3 Mengidentifikasi macam-macam gaya, antara lain: gaya otot, gaya listrik, gaya magnet, gaya gravitasi, dan gaya gesekan yang terdapat di tema 7 pada kelompok eksperimen dan kelompok kontrol untuk dijadikan pretest. Nilai pretest digunakan untuk mengetahui kemampuan peserta didik sebelum diberi perlakuan dengan menggunakan model problem based learning pada kelompok eksperimen dan model project based learning pada kelompok kontrol. Selanjutnya, kedua kelompok tersebut diberi perlakuan sesuai dengan model pembelajaran yang ditentukan dan diberi soal posttest. Soal posttest digunakan untuk mengetahui perbedaan hasil belajar setelah diberi perlakuan model problem based learning dan project based learning.

Teknik pengumpulan data yang digunakan dalam penelitian ini, yaitu membuat kisi-kisi instrumen penilaian, membuat rencana pelaksanaan pembelajaran, melaksanakan uji validitas dan reliabilitas dengan menggunakan SPPS 20 for Windows, melaksanakan penelitian, memberikan posttest, serta menganalisis data. Instrumen pengumpulan data yang digunakan adalah instrumen tes. Tes yang digunakan dalam penilitian ini adalah posttest yang terdiri dari 15 butir isian.

Teknik analisis data yang digunakan dalam penelitian ini adalah teknik deskriptif dan analisis statistik. Uji normalitas dan uji homogenitas dilaksanakan sebagai uji prasyarat sebelum dilaksanakan uji beda rata-rata dan uji hipotesis. Setelah melakukan uji prasyarat dengan uji normalitas dan uji homogenitas, kemudian dilaksanakan uji beda mann-withney untuk menganalisis perbedaan hasil belajar antara model problem based learning dan project based learning.

\section{HASIL DAN PEMBAHASAN PENELITIAN}

Data yang diperoleh dari penelitian ini adalah nilai posttest dan pretest hasil belajar kompetensi dasar 3.3 Mengidentifikasi macam-macam gaya, antara lain: gaya otot, gaya listrik, gaya magnet, gaya gravitasi, dan gaya gesekan.

Tabel 1

Statistik Deskriptif Nilai Posttest dan Pretest Kelompok Eksperimen dan Kontrol

Descriptive Statistics

\begin{tabular}{|l|c|c|c|c|c|}
\hline & $\mathrm{N}$ & $\begin{array}{c}\text { Minimu } \\
\mathrm{m}\end{array}$ & $\begin{array}{c}\text { Maxim } \\
\mathrm{um}\end{array}$ & Mean & Std. Deviation \\
\hline Pretest Eksperimen & 66 & 67.00 & 90.00 & 81.0455 & 7.87485 \\
Posttest Eksperimen & 66 & 66.67 & 93.33 & 82.6263 & 7.00464 \\
Pretest Kontrol & 67 & 67.00 & 90.00 & 81.1642 & 7.87516 \\
Posttest Kontrol & 67 & 66.67 & 100.00 & 94.2288 & 8.75361 \\
Valid N (listwise) & 66 & & & & \\
\hline
\end{tabular}

Berdasarkan tabel 1, dapat dilihat bahwa nilai rata-rata pretest pada kelompok eksperimen sebesar 81,0455 dengan nilai minimum 67 , nilai maximum 90 , dan standar deviasi 7,87485 . Setelah dilaksanakan kegiatan pembelajaran dengan model problem based learning, nilai rata-rata posttest meningkat menjadi 82,6263 dengan nilai minimum 66,67, nilai maksimum 93,33, dan standar deviasi 7,00464. Jumlah peserta didik yang mengikuti posttest sebanyak 66 peserta didik. 
Pada tabel tersebut, dapat dilihat juga nilai rata-rata pretest pada kelompok kontrol sebesar 81,1642 dengan nilai minimum 67 , nilai maksimum 90, dan standar deviasi 7,87516. Setelah dilaksanakan kegiatan pembelajaran dengan model project based learning, nilai rata-rata posttest meningkat menjadi 94,2288 dengan nilai minimum 66,67, nilai maksimum 100, dan standar deviasi 8,75361. Jumlah peserta didik yang mengikuti posttest sebanyak 67 peserta didik.

Tabel 2

Tabel Komparasi Rata-Rata Nilai

Kelompok Eksperimen dan Kontrol

\begin{tabular}{|l|c|c|c|}
\hline \multirow{2}{*}{ Penilaian } & \multicolumn{2}{|c|}{$\begin{array}{c}\text { Rata-Rata Nilai } \\
\text { Kelompok }\end{array}$} & \multirow{2}{*}{$\begin{array}{c}\text { Selisih } \\
\text { Nilai }\end{array}$} \\
\cline { 2 - 3 } & Eksperimen & Kontrol & \\
\hline Pretest & 81,0455 & 81,1642 & 0,1187 \\
\hline Posttest & 82,6263 & 94,2288 & 11,6025 \\
\hline
\end{tabular}

Berdasarkan tabel 2 di atas, dapat diketahui bahwa terdapat perbedaan nilai rata-rata sebelum dan sesudah menggunakan model problem based learning maupun project based learning. Nilai pretest pada kelompok eksperimen sebesar 81,0455 dan kelompok kontrol sebesar 81,1642. Selisih antara nilai pretest pada kelompok eksperimen dan kontrol, yaitu 0,1187. Setelah dilaksanakan kegiatan pembelajaran menggunakan model problem based learning maupun project based learning, nilai rata-rata posttest peserta didik mengalami peningkatan, baik pada kelompok eksperimen maupun kontrol. Nilai posttest pada kelompok eksperimen sebesar 82,6263 dan kelompok kontrol sebesar 94,2288. Selisih antara nilai posttest pada kelompok eksperimen dan kontrol, yaitu 11,6025. Berikut merupakan grafik komparasi data pada kelompok eksperimen dan kontrol yang tersaji dalam gambar 1.

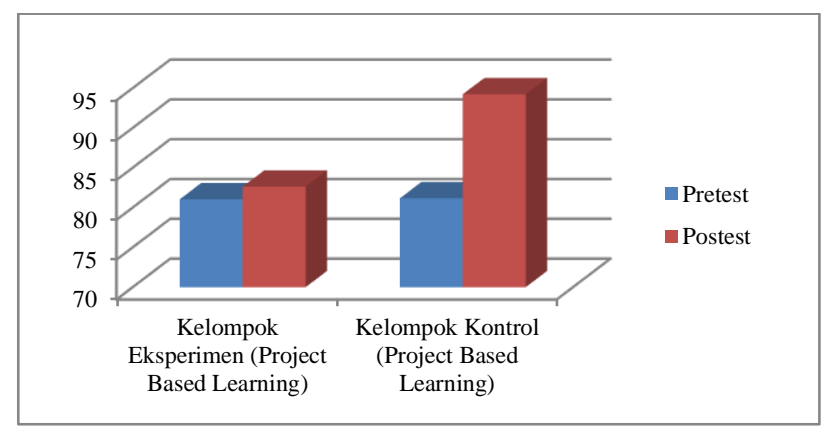

Gambar 1

Grafik Komparasi Data Kelompok Eksperimen dan Kontrol

Berdasarkan gambar 1, dapat diketahui bahwa terdapat peningkatan nilai rata-rata pada kelompok eksperimen yang mendapat perlakuan model problem based learning maupun kelompok kontrol yang mendapat perlakuan model project based learning. 
501 Perbedaan Model Problem Based Learning dan Project Based Learning Terhadap Hasil Belajar Siswa Sekolah Dasar - Francisca Prabasari Winanti Putri , Henny Dewi Koeswanti, Sri Giarti

DOI: https://doi.org/10.31004/edukatif.v3i2.356

Tabel 3

Hasil Uji Normalitas Nilai Pretest-Posttest Kelompok Eksperimen dan Kontrol

One-Sample Kolmogorov-Smirnov Test

\begin{tabular}{|c|c|c|c|c|c|}
\hline & & $\begin{array}{c}\text { Pretest } \\
\text { Eksperime } \\
\text { n }\end{array}$ & $\begin{array}{c}\text { Posttest } \\
\text { Eksperi } \\
\text { men }\end{array}$ & $\begin{array}{l}\text { Pretest } \\
\text { Kontrol }\end{array}$ & $\begin{array}{l}\text { Posttest } \\
\text { Kontrol }\end{array}$ \\
\hline $\mathrm{N}$ & & & 66 & 67 & 67 \\
\hline \multirow{3}{*}{ Normal Parameters ${ }^{\mathrm{a}, \mathrm{b}}$} & Mean & 81.0455 & 82.6263 & 81.1642 & 94.2288 \\
\hline & Std. Deviation & 7.87485 & 7.00464 & 7.87516 & 8.75361 \\
\hline & Absolute & .223 & 248 & 228 & .357 \\
\hline \multirow[t]{2}{*}{ Most Extreme Differences } & Positive & .174 & .165 & .171 & .255 \\
\hline & Negative & -.223 & -.248 & -.228 & -.357 \\
\hline Kolmogorov-Smirnov Z & & 1.808 & 2.017 & 1.868 & 2.923 \\
\hline Asymp. Sig. (2-tailed) & & .003 & .001 & .002 & .000 \\
\hline
\end{tabular}

a. Test distribution is Normal.

b. Calculated from data.

Uji normalitas berfungsi untuk mengetahui apakah data yang dimiliki berdistribusi dengan normal atau tidak. Priyatno (2014) berpendapat bahwa suatu data dapat dikatakan normal apabila nilai signifikansi atau probabilitasnya $>0,05$, berarti bahwa $\mathrm{H}_{\mathrm{o}}$ akan diterima. Berdasarkan tabel 3 , dapat diketahui bahwa nilai signifikansi hasil pretest dan posttest pada Kolmogorov-Smirnov kurang dari 0,05. Oleh karena itu, dapat disimpulkan bahwa data hasil pretest dan posttest pada kelompok eksperimen dan kontrol tidak berdistribusi dengan normal.

\section{Tabel 4}

Hasil Uji Homogenitas Nilai Pretest

Kelompok Eksperimen dan Kontrol

Test of Homogeneity of Variances

Hasil Belajar Peserta Didik

\begin{tabular}{|c|c|c|c|}
\hline $\begin{array}{l}\text { Levene } \\
\text { Statistic }\end{array}$ & df1 & $\mathrm{df} 2$ & Sig. \\
\hline .004 & 1 & 131 & .949 \\
\hline
\end{tabular}

Tabel 5

Hasil Uji Homogenitas Nilai Postest

Kelompok Eksperimen dan Kontrol

Test of Homogeneity of Variances

Hasil Belajar Peserta Didik

\begin{tabular}{|r|r|r|r|}
\hline $\begin{array}{c}\text { Levene } \\
\text { Statistic }\end{array}$ & df1 & df2 & \multicolumn{1}{c|}{ Sig. } \\
\hline .552 & 3 & 262 & .647 \\
\hline
\end{tabular}

Uji homogenitas bertujuan untuk mengetahui apakah varian antara dua kelompok homogen atau tidak. Siregar (2013) berpendapat bahwa suatu data dapat dikatakan homogen apabila nilai signifikansi atau probabilitasnya $>0,05$. Berdasarkan tabel 4 dan 5, dapat diketahui bahwa signifikansi nilai pretest dan posttest pada kedua kelompok menunjukkan angka 0,949 dan 0,647, lebih besar dari 0,05, berarti populasi data nilai pretest maupun posttest pada kelompok eksperimen dan kontrol mempunyai varian yang homogen. 
Berdasarkan uji prasyarat yang dilaksanakan, dapat disimpulkan bahwa data yang dimiliki berdistribusi tidak normal, namun mempunyai varian yang homogen. Oleh karena itu, dapat dikatakan bahwa uji prasyarat tidak terpenuhi, sehingga digunakan uji beda mann-withney.

Tabel 6

Hasil Uji Beda Mann-Withney

Kelompok Eksperimen dan Kontrol

Test Statistics ${ }^{\mathrm{a}}$

\begin{tabular}{|l|r|}
\hline & $\begin{array}{r}\text { Hasil Belajar } \\
\text { Peserta Didik }\end{array}$ \\
\hline Mann-Whitney U & 613.000 \\
Wilcoxon W & 2824.000 \\
Z & -7.345 \\
Asymp. Sig. (2- & .009 \\
tailed) & \\
\hline
\end{tabular}

a. Grouping Variable: Kelompok

Uji beda mann withney dilaksanakan untuk mengetahui ada tidaknya perbedaan rata-rata pada kelompok eksperimen dan kontrol. Berdasarkan tabel 6, dapat diketahui bahwa nilai Asymp. Sig. (2-tailed) sebesar 0,009, kurang dari 0,05. Oleh karena itu, sesuai dengan dasar pengambilan keputusan uji beda mannwithney, dapat disimpulkan bahwa $\mathrm{H}_{\mathrm{o}}$ ditolak dan $\mathrm{H}_{\mathrm{a}}$ diterima. Hal ini berarti bahwa terdapat perbedaan hasil belajar yang signifikan antara penerapan model problem based learning dan project based learning.

Hasil uji beda mann-withney terhadap nilai posttest kelompok eksperimen dan kontrol dapat dijadikan acuan untuk menguji hipotesis. Hipotesis yang diajukan dalam penilitian ini, yaitu:

$\mathrm{H}_{\mathrm{o}} \quad$ : Tidak terdapat perbedaan hasil belajar yang signifikan antara penerapan model problem based learning dengan project based learning terhadap hasil belajar tema 7 siswa kelas IV SDN Kecamatan Tingkir.

$\mathrm{H}_{\mathrm{a}}$ : Terdapat perbedaan hasil belajar yang signifikan antara penerapan model problem based learning dengan project based learning terhadap hasil belajar tema 7 siswa kelas IV SDN Kecamatan Tingkir.

Berdasarkan perhitungan uji beda mann withney yang telah dilaksanakan terhadap nilai posttest pada kelompok eksperimen dan kontrol, diperoleh nilai Asymp. Sig. (2-tailed) sebesar 0,009. Hal ini menunjukkan bahwa nilai Asymp. Sig. (2-tailed) lebih kecil dari 0,05, sehingga $\mathrm{H}_{\mathrm{o}}$ ditolak dan $\mathrm{H}_{\mathrm{a}}$ diterima. Oleh karena itu, dapat disimpulkan bahwa terdapat perbedaan hasil belajar yang signifikan antara penerapan model problem based learning dengan project based learning terhadap hasil belajar tema 7 siswa kelas IV SDN Kecamatan Tingkir.

Penerapan model project based learning dalam penelitian lebih unggul dalam memberikan pengaruh terhadap hasil belajar peserta didik dibandingkan dengan model problem based learning. Model pembelajaran tersebut dapat dikatakan sebagai model pembelajaran yang inovatif, sebab peserta didik tidak hanya dituntut untuk menyelesaikan suatu permasalahan, namun juga diberi kesempatan untuk mengelola kegiatan pembelajaran di dalam kelas dengan melibatkan pekerjaan proyek. Hal tersebut menuntun peserta didik untuk aktif dalam mengikuti kegiatan pembelajaran dan menumbuhkan sikap kerjasama, toleransi, disiplin, jujur, dan percaya diri.

Hasil dari penelitian ini turut diperkuat dengan penelitian dari Harahap \& Prastowo (2014) yang berpendapat bahwa model problem based learning dan project based learning mempunyai signifikansi nilai rata-rata yang berbeda. Penggunaan model project based learning dikatakan lebih efektif daripada model problem based learning. Hal tersebut dibuktikan dengan hasil belajar peserta didik yang diberi perlakuan 
model problem based learning sebesar 77,07, sedangkan hasil belajar peserta didik yang diberi perlakuan model project based learning sebesar 79,30. Sejalan dengan hal tersebut, Sandi et al. (2013) dalam penelitiannya juga berpendapat bahwa penggunaan model project based learning lebih efektif dalam meningkatkan hasil belajar peserta didik.

Berdasarkan hasil analisis data tersebut, maka dapat disimpulkan bahwa terdapat perbedaan antara model problem based learning dengan project based learning dalam pencapaian hasil belajar peserta didik kelas IV SDN Kecamatan Tingkir. Hasil dari penelitian menunjukkan bahwa penerapan model project based learning memberikan pengaruh yang lebih tinggi daripada model problem based learning terhadap hasil belajar peserta didik.

\section{KESIMPULAN}

Berdasarkan analisis data dan hasil penelitian, maka dapat disimpulkan bahwa terdapat perbedaan hasil belajar yang signifikan antara penerapan model problem based learning dengan project based learning terhadap hasil belajar tema 7 siswa kelas IV SDN Kecamatan Tingkir. Hal tersebut berdasarkan pada hasil uji prasyarat yang telah dilaksanakan, yaitu uji normalitas dan uji homogenitas. Hasil uji normalitas menunjukkan bahwa nilai signifikansi hasil pretest dan posttest pada Kolmogorov-Smirnov kurang dari 0,05. Oleh karena itu, dapat disimpulkan bahwa data hasil pretest dan posttest pada kelompok eksperimen dan kontrol tidak berdistribusi dengan normal. Hasil dari uji homogenitas menunjukkan bahwa signifikansi nilai pretest dan posttest pada kedua kelompok sebesar 0,949 dan 0,647, lebih besar dari 0,05, berarti populasi data nilai pretest maupun posttest pada kelompok eksperimen dan kontrol mempunyai varian yang homogen. Berdasarkan uji prasyarat yang dilaksanakan, dapat disimpulkan bahwa data yang dimiliki berdistribusi tidak normal, namun mempunyai varian yang homogen. Oleh karena itu, dapat dikatakan bahwa uji prasyarat tidak terpenuhi, sehingga digunakan uji beda mann-withney. Hasil uji beda mann-withney menunjukkan bahwa nilai Asymp. Sig. (2-tailed) sebesar 0,009, kurang dari 0,05. Oleh karena itu, sesuai dengan dasar pengambilan keputusan uji beda mann-withney, dapat disimpulkan bahwa $\mathrm{H}_{\mathrm{o}}$ ditolak dan $\mathrm{H}_{\mathrm{a}}$ diterima. Hal ini berarti bahwa terdapat perbedaan hasil belajar yang signifikan antara penerapan model problem based learning dan project based learning.

Peneliti memberi saran agar pengajar menerapkan model project based learning dalam kegiatan pembelajaran di kelas. Model pembelajaran tersebut sesuai dengan tuntutan kurikulum 2013, yaitu wajib menciptakan keaktifan peserta didik pada saat kegiatan pembelajaran berlangsung. Namun dalam penerapannya, pengajar wajib memperhatikan karakteristik peserta didik.

\section{DAFTAR PUSTAKA}

D, N. K. N. A. S., Garminah, N. N., \& Pudjawan, K. (2013). Pengaruh Penggunaan Model Pembelajaran Berbasis Proyek (Project Based Learning) terhadap Hasil Belajar IPA Siswa Kelas IV SDN 8 Banyukuning. Mimbar PGSD Undiksha, 1(1).

Depdiknas. (2003). Undang-Undang Republik Indonesia Nomor 20 Tahun 2003 tentang Sistem Pendidikan Nasional. Departemen Pendidikan Nasional.

Fiana, R. O., Relmasira, S. C., \& Hardini, A. T. A. (2019). Perbedaan Penerapan Model Project Based Learning dan Problem Based Learning terhadap Hasil Belajar Matematika Kelas 4 SD. Jurnal Basicedu, $3(1), 157-162$.

Harahap, M. A., \& Prastowo, P. (2014). Perbedaan Hasil Belajar Siswa Menggunakan Model Pembelajaran Project Based Learning dan Problem Based Learning Pada Materi Pencemaran Lingkungan. In Prosiding Seminar Nasional Biologi dan Pembelajarannya. Universitas Negeri Medan. 
504 Perbedaan Model Problem Based Learning dan Project Based Learning Terhadap Hasil Belajar Siswa Sekolah Dasar - Francisca Prabasari Winanti Putri , Henny Dewi Koeswanti, Sri Giarti

DOI: https://doi.org/10.31004/edukatif.v3i2.356

Hosnan. (2014). Pendekatan Saintifik dan Kontekstual dalam Pembelajaran Abad 21. Ghalia Indonesia.

Kemendikbud. (2013a). Lampiran Peraturan Menteri Pendidikan dan Kebudayaan Nomor 67 Tahun 2013 tentang Kerangka Dasar dan Struktur Kurikulum Sekolah Dasar/Madrasah Ibtidaiyah. Kementerian Pendidikan dan Kebudayaan.

Kemendikbud. (2013b). Peraturan Menteri Pendidikan dan Kebudayaan Republik Indonesia Nomor 81A Tahun 2013. Kementerian Pendidikan dan Kebudayaan.

Koeswanti, H. D. (2015). Problem Based Learning: Suatu Metode Pembelajaran Untuk Meningkatkan Keterampilan Memecahkan Masalah dan Mengembangkan Kemampuan Berpikir Logis. Jurnal Widya Sari, 17(2), 31-36.

Priyatno, D. (2014). SPSS 22 Pengolahan Data Terpraktis. CV Andi Offset.

Sani, R. A. (2014). Pembelajaran Saintifik untuk Implementasi Kurikulum 2013. Bumi Aksara.

Siregar, S. (2013). Metode Penelitian Kuantitatif: Dilengkapi Perbandingan Perhitungan Manual dan SPSS. Kencana Prenada Media Group.

Sufairoh. (2016). Pendekatan Saintifik dan Model Pembelajaran K-13. Jurnal Pendidikan Profesional, 5(3), 120.

Sukmadinata, N. S. (2012). Metode Penelitian Pendidikan. Remaja Rosdakarya.

Suyono Hariyanto. (2011). Belajar dan Pembelajaran: Teori dan Konsep Dasar. Remaja Rosdakarya.

Taniredja, H. T. (2011). Model-Model Pembelajaran Inovatif. Alfabeta. 